\title{
Comparative Study of the Structure of the Os Calcaneum in Insectivores and Rodents
}

\section{Studium porównawcze budowy kości piętowej u owadożernych i gryzoni}

\author{
[With 50 figs: and 2 tables]
}

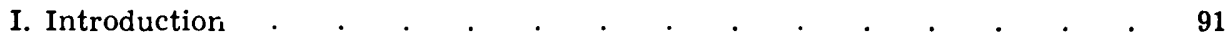

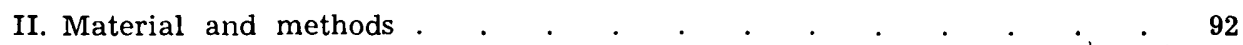

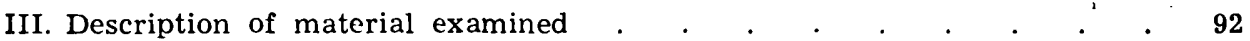

IV. Comparative review of the structure of os calcaneum . . . . . . 114

V. Discussion . . . . . . . . . . . . . . . . . 117

VI. Conclusions . . . . . . . . . . . . . . . . . 125

References . . . . . . . . . . . . . . . . . 125

Streszczenie . . . . . . . . . . . . . . . . 126

\section{INTRODUCTION}

The present study forms a continuation of the research carried out by the authoress on the sesamoid bones of the autopodium in Insectivora and Rodentia (R om ankowowa, 1960). A separate study was devoted to os calcaneum on account of the considerable differences occurring in its structure in different species. This element, important in the dynamics of the limb, has been given very little comparative treatment in world literature. An interesting work, comprehensively comparative, on this bone in 10 orders of mammals is the publication by $\mathrm{Stain} s$ (1959) concerned with chiefly North American forms.

In describing the bone use was made of the terms set out in Fig. 1, in accordance with Polish Anatomical Nomenclature (1958). I have termed the articular surface on which the facies articularis cuboidea is situated, in accordance with its natural positioning in mammals, the cranial surface. S t a i n s (1959) uses the name "distal end" which in fact is justified from the philogenetic aspect.

The os calcaneum formed an elongated element in all the species examined. On the dorsal surface of the bone there are two, and sometimes three articular surfaces serving to connect it with astragalus on the cranial end of the bone - an articular surface serving to connect it with os cuboideum. Sustentaculum talare is situated on the medial surface and trochlea peronealis on the lateral surface of the bone. 
The aim of the study was to make a comparative investigation of the os calcancum in different genera and species of the orders of mammals examined.

Acknowlcdgements: I have fleasure in expressing my warmest gratitude to Professor Dr. Wladys?aw W ęgor ek for making it possible for me to carry out the wirk in the Institute of Plant Protection, to Professor Dr. Henryk Szarsk i fcr his kindness in consulting the work with me, to Professor Dr. Zbigniew $\mathrm{R} \mathrm{y} \mathrm{zie-}$ wic $z$ for his helpful remarks and for giving me access to valuable information in literature.

I am also greatly indebted to the late Professor Dr. August Dehnel, whose* sudden death occurred recently, for his valuable guidance, many works of great assistance in literature and material consisting of steppe mammals which made it possible to complete my work.

\section{MATERIAL AND METHODS}

Material was collected as from 1950. Part of the specimens come from my own captures made in the Wroclaw district. The remainder of the material was put at my disposal by Professor August Dehnel and Professor Waclaw Skuratowicz. The extra-European species I obtained by courtesy of W.C. Osman Hill of the Zoological Society of London.

I am extremely grateful for all the material put at my disposal.

All the species examined are set out in table 1. A total of 251 limbs of individuals belonging to 50 species were examined. The whole of the material was stained with alizarine and prepared under a dissecting microscope. Measurements were made by means of Zeiss measuring apparatus (Carl Zeiss, Jena). Each measurement was repeated 3 times.

\section{DESCRIPTION OF THE MATERIAL EXAMINED}

Amblysomus hottentotus S m ith, (Fig. 1)

The shaft of the bone is bilaterally flattened, twisted in the long axis, the terminal ends are bent in a medial direction. The cranial and caudal surfaces of the bone are parallel to each other, cut off obliquely in relation to the long axis. The dorsocranial region is flattened, developed in the medial direction. The cranial surface is formed like a triangle with arched concave arms, the apices of the triangle are situated on trochlea peronealis, on the plantocranial and dorsomediocranial ends of the shaft.

Sustentaculum talare is flattened, very broad, slightly convex on the : side of the dorsal surface. The outline of the free edge of the process is ; bow-shaped, the apex is shifted in the caudal direction. Sulcus tendinis; $m$. flex. dig. fibularis is broad and deep, penetrating into the shaft of the : bone. The bottom of the sulcus is covered with cartilage, with which the : sesamoid bone of the tendon is connected. Trochlea peronealis is a thick: arched process, set laterodorsally on the cranial end of the bone, the long; axis of the process is situated at an acute angle to the long axis of the ? bone. Sulcus tend. $m$. peronei longi is gutter-shaped, broad, occupying the 
whole height of the process. The shape of facies articularis cuboidea is similar in general outline to a triangle, with concave-convex arms. The articular surface reaches to the base of trochlea peronealis on the lateral side. The base of the triangle, situated medially, is indented in the form of an arch. Facies articularis talaris anterior is elongated, ellipsoid, the ends appearing as though crushed. It is situated on the mediodorsal surface of the cranial end of the investigated bone. Facies articularis talaris media is large, situated with the long axis at a right angle to the axis of the bone, concave along the craniocaudal axis. Facies articultris talaris post. is situated on the extension of the long axis of the previous surface, from which it is separated by sulcus calcanei running lengthwise. It is relatively small, with oval outline, occupying the medial surface of the dorsal prominence of the bone.

Erinaceus europaeus Linnaeus, 1758 (Fig. 2)

The os calcaneum is sturdy, elongated, slightly twisted. The cranial and caudal surfaces of the bone are almost parallel, cut obliquely. Sulcus tendinis calcanei is relatively shallow. Sustentaculum talare is a distinct, flat process, with a straight caudal border, convex medially. Sulcus tendinis $m$. flex. dig. fibularis is wide and shallow. Trochlea peronealis is a faintiy marked node situated cranially on the lateral surface of the bone. Facies articularis cuboidea is concave along the mediolateral axis, of irregular rounded shape. Facies articularis talaris media is concave along the craniocaudal axis, oval. Facies articularis talaris post. occupies the dorsal and medial surface of the dorsal prominence of the bone. Both parts of the articular surface meet in the medial line at an angle similar to a right angle.

Sorex Lin na e us, 1758 (Figs. 3, 4, 5, 6)

The os calcaneum is elongated. The terminal half of the bone is bilaterally flattened. The bone is sturdy in S. araneus, slender in S. minuius. The lateral surface of the bone is slightly convex, the medial surface slightly concave. The cranial and caudal surfaces of the bone are parallel, cut off obliquely. Sulcus tendinis calcanei is relatively deep. Sustentaculum talare is smaller in $S$. minutus. In $S$. araneus this process is similar in shape to a triangle, in the remaining species it is more like a trapezium with a wider caudal edge, which is a straight line in $S$. caecutiens, slightly concave-convex in $S$. araneus, and strongly concave-convex in $S$. minutus. The medial border of $S$. araneus is a faintly convex arch, which reaches to the cranial end of the shaft of the bone. In S. caecutiens and in S. minutus this border is strongly concave, as a result of which the process is 
shifted more caudally. Sulcus tendinis m. flex. dig. fibularis is deep in $S$. araneus and $S$. caecutiens, slightly shallower in $S$. minutus. Trochlea peronealis is a flattened process set in the cranial region of the lateral surface of the bone. In $S$. minutus and $S$. caecutiens the caudal border converges with the shaft in an arch, in $S$. araneus it is separated by a sulcate indentation. The cranial border of the process in both species passas on to the cranial border of the shaft, in $S$. araneus it is slightly withdrawn caudally and ends on the lateral surface of the shaft. Sulcus tend. mm.

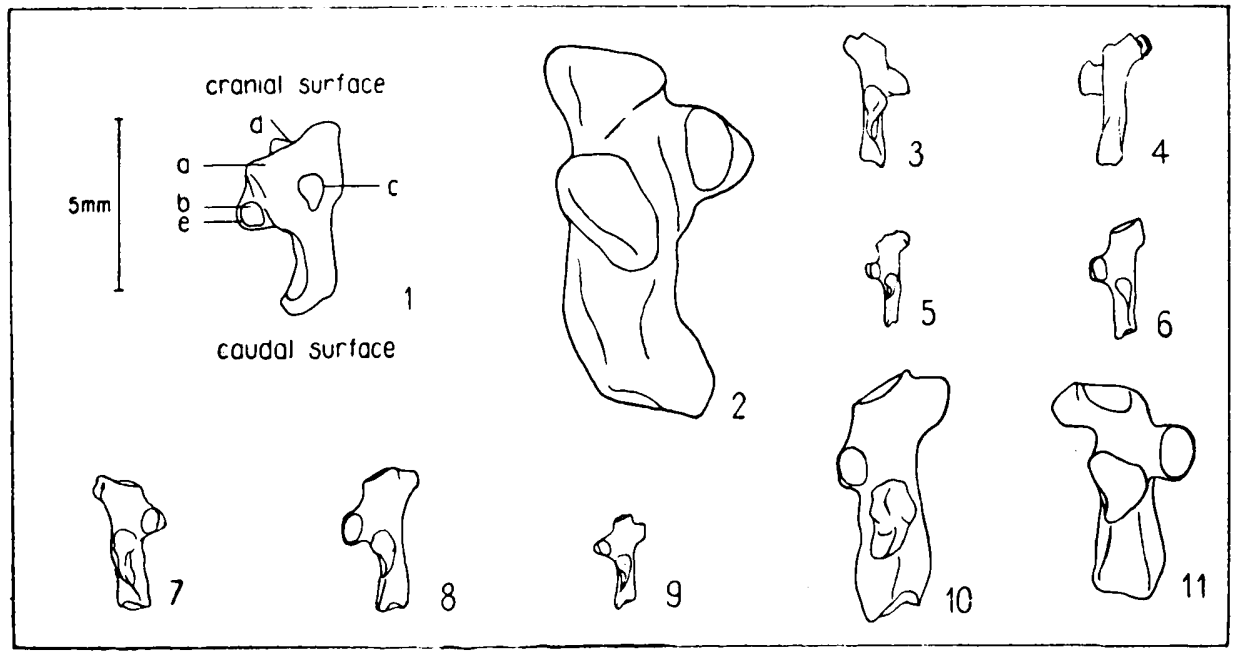

Figs. 1-11. Structure of the Os calcaneum in Insectivora.

1 - Amblysomus hottentotus, R., d.

2-Erinaceus europaeus, L., d.

3 - Sorex araneus, L., d.

4 - Sorex araneus, L., p.

$5-$ Sorex minutus, R., d.

6 - Sorex caecutiens, R., d.
7 - Neomys fodiens, L., m-d.

8 - Blarina brevicauda, R., d.

9 - Crocidura suaveolens, $\mathrm{R}$., $\mathrm{d}$.

$10-$ Suncus murinus, R., m-d.

11 - Talpa europaea, L., d.

Key to the lettering: a - Facies articularis talaris anterior, b - Facies articularis talaris media, c - Facies articularis talaris posterior, d - Facies articularis cuboidea, e - Sustentaculum talare, R. - right, L. - left, d. - dorsally, p. - plantarly, m-d. - mediodorsally.

peroneorum is slightly shallower on the dorsal surface of the process, deeper on the plantar surface. The axis connecting sustentaculum talare with trochlea peronealis is situated obliquely in relation to the long axis of the bone. Facies articularis cuboidea in $S$. araneus is roundish, in $S$. $m i$ nutus similar to a triangle with rounded angles, largest in $S$. caecutiens, slightly oval in shape. Facies articularis talaris media is oval, concave. Facies articularis calcaneotalofibularis is complex in structure. The cranial part, situated on the dorsal surface of the shaft, is nodally convex, caudal, occupying the medial surface of the dorsal arching of the bone - 
and is concave. The whole articular surface is, as it were, lightly chiselled from the lateral side, and as a result a ridge runs along the crest of the articular surface. The cranial node in the region of the bone is emphasised, round in $S$. araneus, emphasised and oval in $S$. caecutiens, while in $S$. minutus its structure is delicate, and oval in shape. Facies articuiaris talaris media et posterior are separated from each other by a deep sulcus calcanei.

Neomys $\mathrm{K}$ a u p, 1829, (Fig. 7)

The bone is most massive in $N$. fodiens, the lateral border is slightly arched and convex in $N$. fodiens, straight in $N$. anomalus, slightly concave medially. The caudal end of the bone is broadened, cut latero-dorsally, sulcus tendinis calcanei is broad. The deep sulcus tend. m. flex dig. fibularis cuts into the shaft of the bone. The free edge has the outline of a semi-circular arch in $N$. fodiens, a nosed profile in $N$. anomalus. Trochlea peronealis occupies the laterodorsal surface of the cranial end of the os calcaneum. This is a broad spade-shaped process in $N$. fodiens, slightly narrower in $N$. anomalus, the cranial border of which lies in the extension of the cranial border of the remaining part of the bone. The plantolateral sulcus tend. $m$. peronei longi is deeper than sulcus tend. $m$. peronei brevis. Facies articularis cuboidea occupies the proximal end of the shaft, is situated obliquely to the long axis of the bone. It is relatively large, triangular, with rounded angles, concave in the shape of a basin. Facies articularis talaris media is oval, concave in the shape of a basin. Facies articularis calcaneotalofibularis post. is similar in structure to Sorex sp. The tuber of the cranial region is emphasised, oval. The caudal region is slightly shorter in $N$. fodiens. Sulcus calcanei on the border of both surfaces is elongated, relatively deep.

Blarina brevicauda (S a y, 1823), (Fig. 8)

The bone is sturdy, relatively large, bilaterally flattened. Sulcus tendinis calcanei is situated on the laterocaudal surface of the bone, is relatively deep. Sustentaculum talare is flattened, emphasised, semi-circular process. Sulcus tendinis musculi flex. dig. fibularis is deep, runs obliquely in relation to the long axis of the bone. Trochlea peronealis is relatively small. The cranial edge of the trochlea is connected by a faintly convex arch with the edge of facies articularis cuboidea. Sulcus tend. mm. peroneorum is situated on the lateroplantar and plantar surface of the process. Facies articularis cuboidea is concave in the form of a basin, triangular, relatively large. Facies articularis talaris media is concave, oval. Façies articularis calcaneotalofibularis post. - similar to that in 
Sorex sp. The cranial part of the articular surface is nodularly arched, ellipsoid, convex from the medial side, concave from the lateral side. The dorsal edge of the articular surface in S-shaped. Facies articularis talaris media et posterior are separated from each other by a relatively deep sulcus.

\section{Crocidura W a g l e r, 1832 (Fig. 9)}

The bone is small in C. suaveolens laigest in C. miya. Sulcus tendinis calcanei is situated on the caudolateral surface of the bone. The shaft of the bone is slightly twisted, bilaterally flattened. Sustentaculum talare is slender, nose-shaped. The caudal edge is concave-convex. Sulcus tend. $m$. flex. dig. fibularis, which is shallow in C. suaveolens, indented into the shaft in the remaining species, runs diagonally to the long axis of the bone. Trochlea peronealis is earshaped. Sulcus tend. $m$. peronei longi is situated on the lateroplantar surface of the process, sulcus tend. m. peronei brevis on the dorsal surface and runs diagonally.

Facies articularis cuboidea is situated on the mediocranial surface of the bone, is depressed in the form of a basin, relatively large, but does not, however, occupy the whole terminal surface. Facies articularis talaris media is concave, basin-shaped. Facies articularis calcaneotalofibularis post. is similar to that in Sorex $\mathrm{sp}$. The cranial part of the articular surface is nodular, slightly oval. In the distal part there is a basin-shared depression on the medial surface of the dorsal prominence of the bone. The S-shaped edge runs throughout the whole length of the articular surface. Both articular surfaces are separated from each other by a shallow, fairly wide sulcus.

Suncus Ehrenberg, 1833 (Fig. 10)

The bone is long, bilaterally flattened, bacilliform, the caudal surface of the bone is cut obliquely, and differs as to the size in both species - in $S$. coeruleus it is far greater and more massive. Sustentaculum talare is flattened, semi-circular. Sulcus tendinis $m$. flex dig. fibularis is deep and runs diagonally. Trochlea peronealis in S. montanus is relatively short, the outline of the free edge of the process is similar to a parrot's beak, in $S$. coeruleus it is slightly longer, running in the opposite direction. Sulcus tend. $\mathrm{mm}$. peroneorum are deep, situated on the lateral and plantar surfaces of the trochlea. Facies articularis cuboidea is relatively large, rounded, concave in the form of a basin. Facies articularis talaris media is large, oval, slightly concave, situated at an angle of about $45^{\circ}$ to the long axis of the bone - enters deeply into the shaft of the bone in the cranial direction, Facies articularis calcaneotalofibularis posterior is 
elongated, slightly flattened, the outline is clavate, the part situated cranially being spherical in outline, the part situated caudally narrowed. An S-shaped margin runs through the middle of the articular surtace. Sulcus calcanei is relatively narrow and shallow.

Talpa europaea Lin n a u s, 1758 (Fig. 11)

The os calcaneum is slender, elongated, slightly twisted in the long axis, bilaterally flattened. The cranial region of the bone is massive, the distal region widened dorsoventrally. Sustentaculum talare is relatively large, is similar in shape to a rectangle. It is flattened and set at an angle of about $45^{\circ}$ to the long axis of the bone. Sulcus tendinis m. flex. dig. fibularis is deep. The cranial margin of sustentaculum is separated by a sulcate indentation from the cranial surface of the shaft. Trochlea peronealis is a broad process protruding on to the lateral surface of the proximal region of os calcaneum. Sulcus tend. mm. peroneorum is slightly deeper on the dorsal surface than on the plantar surface. Facies articularis cuboidea is large, situated craniomedially at an angle of $45^{\circ}$ in relation to the long axis of the bone, is concave in the form of the basin. Facies articularis talaris media is concave in the form of a basin, is situated on the dorsal surface of sustentaculum and is about half as small as the following surface. Facies articularis calcaneotalofibularis post. is large, extends from halfway along the length of the dorsal surface of the bone in the direction of its cranial end. It has a complex, saddle-shaped structure. The caudal part of the surface is nodularly convex, with a bow-shaped margin running laterocaudally (in the region of contact with the fibula). As the articular surface proceeds in a cranial direction it falls steeply, then is slightly raised. Both articular surfaces are separated from each other by a flat sulcus calcanei.

\section{Sciurus vulgaris L i n n e us, 1758 (Figs. 12, 13)}

The craniai region of the bone is flattened dorsoplantarly, the caudal region lateromedially. The shaft of the bone is twisted in the long axis. The cranial and caudal surface are set vertically to the long axis of the bone. Sulcus tend. calcanei is a broad, relatively shallow groove occupying the caudal surface of the bone. Sustentaculum talare is massive, relatively large, flattened on the dorsal side, convex on the plantar side. The free margin of the process is shaped like a sharp bow. Sulcus tend. m. flex. dıg. fibularis forms a depression on the border of the process and shaft of the bone. Trochlea peronealis is shaped like a sectional arch in outiine, occupies a laterocranial situation. Sulcus tend, mm. peroneorum oçcupies 
a lateral position. Facies articularis cuboidea has an outline similar to a circle, concave in a basin-shape. The margin of the articular surface extends in the shape of a proboscis in a cranial direction. Facies articularis talaris media is large, oval. Facies articularis talaris post. is shaped like an elongated isosceles triangle. It is situated on the dorsomedial surface of the dorsal prominence of the os calcaneum. The dorsal margin of the bone from the caudal end of the articular surface is concave, similar to a sectional arch in outline.

Ratufa indica (E r x le be n, 1777), (Fig. 14)

The shaft of the bone is slightly twisted, the terminal ends of the bone are bent in the direction of the axis of the foot. The cranial region is the broadest, the bone narrows in the medial region, and widens slightly in the caudal region. The cranial and caudal margins are cut at a right angle in relation to the long axis of the bone. The caudal region of the bone is bilaterally flattened. Sulcus tend. calcanei, which is deep, occupies the central part of the caudal surface. Sustentaculum talare is arched in the form of a bow, the long axis directed cranially. The process is flattened, slightly concave from the side of the dorsal surface, slightly convex on the plantar surface side. Trochlea peronealis is similar to a sectional bow in outline, and is flat. Sulcus tend. $\mathrm{mm}$. peroneorom occupies a lateral position, is deep, and has thick cylindrical edges. Facies articularis cuboidea is similar to a circle in shape, is concave in the form of a basin. Facies articularis talaris ant. is situated on the cranial end of the dorsal surface of the shaft, is similar to a rectangle, the long axis is set vertically to the long axis of the bone. Facies articularis talaris media is mushroom-shaped, slightly concave-convex. Facies articularis talaris post. is tongue-shaped, convex on the side of the lateral margin, sloping downwards from the cranial and mediolateral side. Both articular surfaces are set at an obtuse angle. Sulcus calcanei is relatively broad, deep and short. The cone-shaped thickened edge of the dorsal margin runs from the rounded end of facies articularis talaris post. in a caudal direction.

Cynomys ludovicianus (Ord, 1815), (Fig. 17)

The bone is sturdy, slightly twisted in the long axis. The cranial region of the bone is broader, on the distal side the bone is flattened bilaterally. The cranial surface is set at a right angle, the caudal surface diagonally in relation to the long axis of the bone. On the plantar surface of the bone there is a broad diagonally directed depression. Sulcus tend. calcanei occupies the whole breadth of the caudal end of the bone, is slightly 
depressed. Sustentaculum talare is thick, flattened on the side of the dorsal surface, convex on the plantar surface side. The outline of the free margin of the bone is similar to a normal bow. Sulcus tend. m. flex. dig. fibularis is broad, bordered on the side of the bone shaft by a broad and relatively high margin. Trochlea peronealis is similar to a sectional bow in outline, is situated at the height of sustentaculum talare. The axis connecting both processes is situated vertically to the long axis of the bone. Sulcus tend. $\mathrm{mm}$. peroneorum runs parallel on the dorsal side of the process, and diagonally in relation to the long axis of the bone on the plantar side. Facies articularis cuboidea is similar to a circle in outline, and is depressed in the form of basin. Facies art. talaris ant. is slightly convex, oval. Facies articularis talaris media is oval, slightly concave, shifted to the marginal region of sustentaculum talare. Facies art. talaris post. is oval, elongated, convex along the lateromedial axis. Sulcus calcanei is very wide and shallow. The long axes of both the above articular surfaces are almost parallel.

\section{Citellus suslicus (G ï ld e ns t a ed t, 1770), (Figs. 15, 16)}

The cranial region of the bone is relatively strongly flattened on both sides. The terminal ends are bent medially, the shaft is slightly twisted in the long axis. There are two massive elongated nodes on the plantar surface of the bone: the craniomedial and plantolateral. An eminence runs from the first of them forming a relatively high peri-axial margin of sulcus tendinis m. flex. dig. fibularis. Trochlea peronealis is arched in bow form, sulcus tend. $m$. peronei longi runs plantolaterally. This process is slightly higher than sustentaculum talare. A line drawn through the apices of both processes is vertical to the long axis of the bone. Facies articularis cuboidea is situated slightly diagonally (craniodorsally), and is oval. Facies articularis talaris ant., the smallest of those examined in this species - occupies the radial surface of the cranioterminal process of the dorsal surface of the bone, is triangular. Facies articularis talaris meaia is oval, slightly concave. Facies articularis talaris post. is arched high, oval, runs diagonally to the long axis of the bone.

Tamias striatus (L i n n e us, 1758), (Fig. 18)

The shaft of the bone is dorsoventrally flattened in the mediocranial region, sculptured in the shape of a roof in the caudal region of the bone. The cranial and caudal surfaces are cut at a right angle in relation to the long axis of the bone. Sulcus tend. calcanei is broad, concave, similar to a sectional arch in outline. Sustentaculum talare is flat on the dorsal side, convex on the plantar side. The free edge of the process is shaped like 


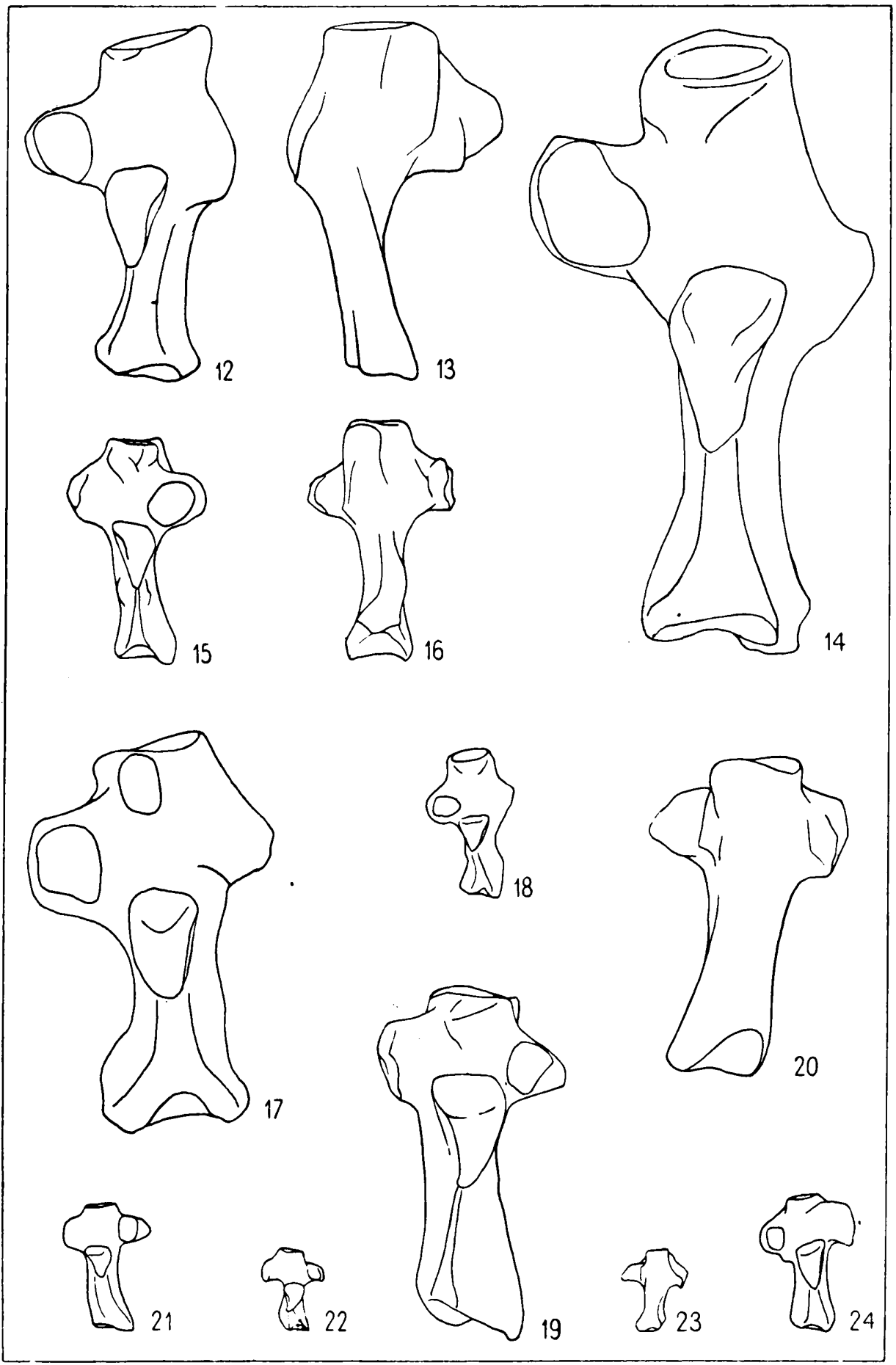

Figs. 12-50. Structure of the Os calcaneum in Rodentia. 


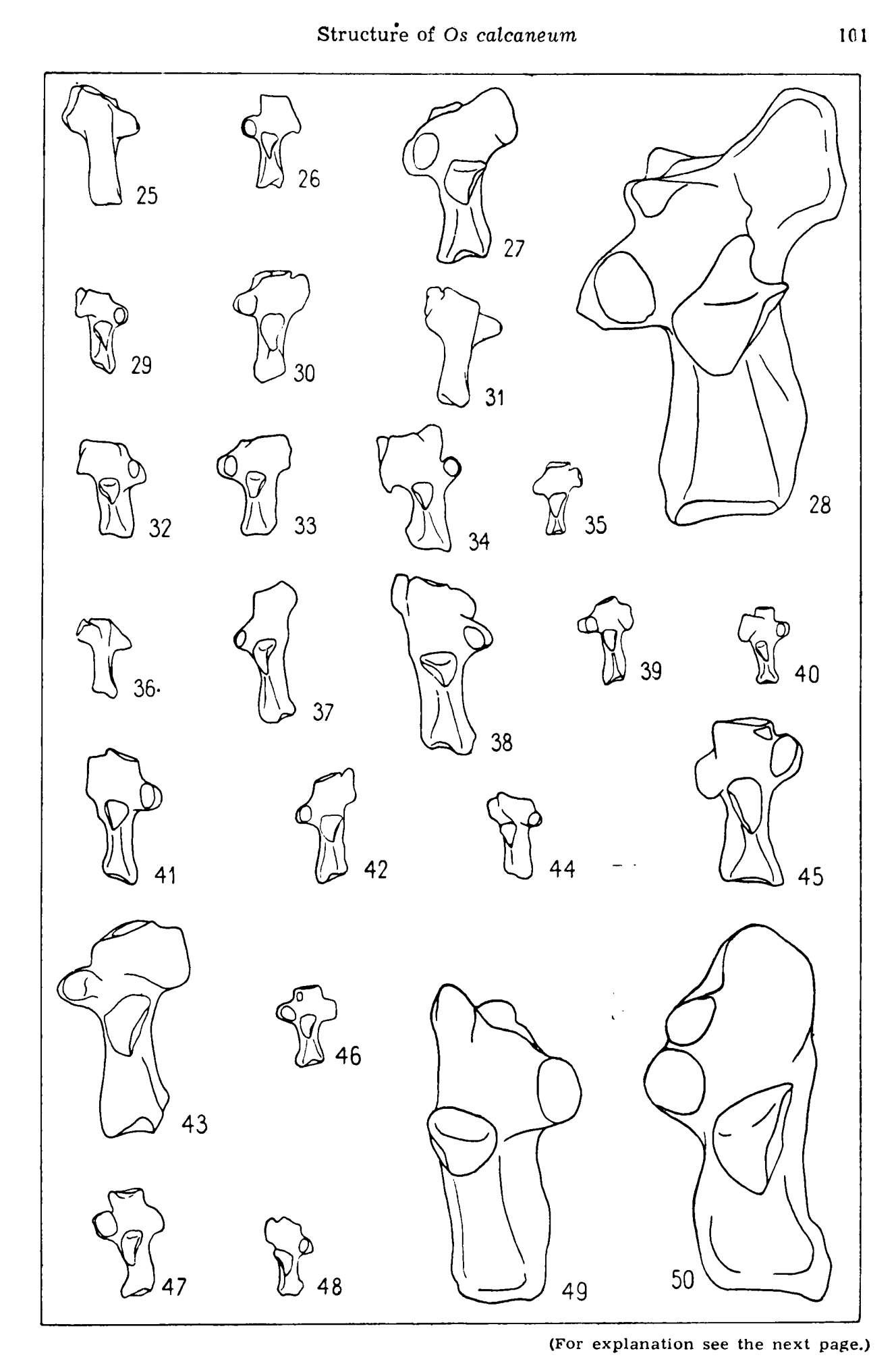


a semi-circular arch, shifted slightly in the caudal direction. Sulcus terd. $m$. flex. dig. fibularis runs on the prominence between the shaft and the process. Trochlea peronealis is shaped like a sectional arch in outiine, is shifted in the direction of the middle of the lateral surface of the bone. Sulcus tend. mm. peroneorum is gutter-shaped, and is situated on the lateroplantar surface of the process. A line drawn through the apices of both processes is vertical to the long axis of the bone. Facies articularis cuboidea is similar to a circle in outline, is depressed in the form of a basin, slightly inclined in the dorsal direction. Facies articularis talaris media is relatively large, occupies the dorsal surface of sustentaculum. Facies articularis talaris post. is similar in shape to an elongated isosceles triangle. It occupies the dorsomedial surface of the dorsal prominence of the bone. Sulcus calcanei is short, relatively deep. The outline of the dorsal margin of the bone from facies articularis talaris post. is archshaped in the caudal direction.

Phodopus sungorus (P a lla s, 1773), (Figs. 22, 23)

The cranial and caudal surfaces of the bone are parallel to each other, set obliquely to the long axis of the bone (the lateral surface protrudes more cranially). The shaft of the bone is narrower in the central region, the cranial end is developed in a medial direction, as a result of which the bone is similar in shape to an elongated letter $\mathrm{S}$. The long axis of the bone is twisted. On the plantar surface of the bone there are two nodes: cranio-

Explanations to Figs. 12-50.

12 - Sciurus vulgaris, R., d.

13 - Sciurus vulgaris, R., p.

14 - Ratufa indica, R., d.

15 - Citellus suslicus, L., d.

16 -Citellus suslicus, L., p.

17 - Cynomys ludovicianus, R., d.

18 - Tamias striatus, R., d.

19 - Cricetus cricetus, L., d.

20 -Cricetus cricetus, L., p.

21 - Mesocricetus auratus, L., d.

22 - Phodopus sungorus, L., d.

23 - Phodopus sungorus, L., p.

24 - Lemmus lemmus, R., d.

25 - Lemmus lemmus, R., p.

26 - Clethrionomys glareolus, R., d.

27 - Arvicola terrestris, R., d.

28 - Ondatra zibethica, R., d.

29 - Pitymys subterraneus, L., d.

$30-$ Microtus brandti, R., d.

31 - Microtus brandti, R., p.

32 - Microtus orcadensis, L., d.
33 - Microtus oeconomus, R., d.

$34-$ Microtus nivalis, L., $\mathrm{d}$.

35 -Lagurus lagurus, R., d.

36 - Lagurus lagurus, R., p.

37 - Gerbillus gerbillus, R., d.

38 - Meriones shawi, L., d.

39 - Vandeleuria oleracea, R., d.

$40-$ Micromys minutus, L., d.

41 - Apodemus flavicollis, L., d.

42 - Apodemus agrarius, R., d.

43 - Rattus rattus, R., d.

44-Mus musculus, L., m-d.

$45-$ Glis glis, L., d.

46 - Muscardinus avellanarius, R., d.

47 - Dryomys nitedula, R., d.

48 - Sicista betulina, L., m-d.

49 - Cavia porcellus, L., m-d.

50 - Chinchilla laniger, R., d.

Key to the lettering: R. - right, L. - left, d. - dorsally, p. - plantarly, m-d. - mediodarsally. 
and caudomedial. Sulcus tend. calcanei is relatively broad, the groove running diagonally through the caudal end of the bone from the lateroplantar side in the mediodorsal direction. Trochlea peronealis and sustentaculum talare are prominent, a line drawn through the apices of both processes is situated slightly diagonally. Sustentaculum talare is broad, trochlea peronealis shifted slightly cranially, longer and narrower than the first process. Sulcus tend. $m$. peronei longi is broad and situated on the plantar surface of the process. Facies articularis cuboidea is rounded, and has an irregular concave marginal line on the medial side, is slightly concave, situated in the mediodorsal plane. Facies articularis talaris ant. is small, situated on the mediodorsal surface of the shaft, facies articularis talaris media - oval, slightly concave, facies articularis talaris post. is large, tongue-shaped, convex. The long axis of the articular surface runs in a dorsomedial direction.

Cricetus cricetus (L i n n a e u s, 1758), (Figs. 19, 20)

The shaft of the bone is massive, bilaterally flattened in the caudal region, and broadened in the cranial region. The caudal surface of the shaft is obliquely cut. Sulcus tend. calcanei is relatively shallow. The shaft of the bone is slightly arched in the medial direction. The axis connecting sustentaculum talare and trochlea peronealis is set at a right angle to the long axis of the bone. Sustentaculum talare is relatively small, flattened, convexly arched. Trochlea peronealis is larger than sustentaculum talare, massive. Sulcus tend. $m$. peroneus longus is situated on the lateroplantar surface of the process, tendo $m$. peroneus brevis runs in a hollow on the dorsal surface of the process. Facies articularis cuboidea occupies the cranial surface of the shaft, is concave, similar to a circle in shape. Facies articularis talaris ant. is relatively small, similar in shape to a triangle, situated on the medial surface of the cranial nodes of the bone. Facies articularis talaris media is elongated, oval. In some of the individuals examined both surfaces are in contact. Facies articularis talaris post. is elongate, concave-convex, situated on the dorsomedial prominence of the bone. The shaft of the bone seen from the plantar side broadens gradually as it passes to the cranial part. On the border of the shaft and sustentaculum talare a flat threshold prominence runs which is the periaxial margin of sulcus tend. m. flex. dig. fibularis.

Mesocricetus auratus (W a te $\mathrm{r}$ h o u se, 1839), (Fig. 21)

The cranial and caudal region of the bone are broader, the mediai is bilaterally flattened and narrower. The caudal end of the bone is bent in 
the direction of the axis of the foot. Sulcus tend. calcanei is broad and very shallow. Sustentaculum talare is flattened, the free edge is shaped like a sharp bow. Sulcus tend. $m$. flex. dig fibularis is shallow. Trocinlea peronealis is shaped like a bow in outline. Sulcus tend. $\mathrm{mm}$. peroneorum forms a deep groove, situated laterodorsally on the process. Facies articularis cuboidea is round, concave in the shape of basin. Facies articularis talaris media is oval, concave. Facies articularis talaris post. is elongated along the long axis of the bone, broad, dorsomedially convex. Sulius calcanei is broad.

Lemmus lemmus (L i n n a u s, 1758), (Figs. 24, 25)

The cranial surface of the bone is vertically cut, the caudal surface slightly obliquely cut. The bone is flattened dorsoplantarly. Sulcus tend. calcanei is broad. The plantar surface of the bone is slightly concave. Sustentaculum talare is massive, relatively large, flattened, arched in the form of a bow. Sulcus tend. $m$. flex. dig. fibularis is relatively deep, forming the border between the process and shaft of the bone. Trochiea peronealis is shaped like the sharp edge of a battle-axe. Sulcus tend. $m$. peroneorum on the plantar surface of the process is relatively deep and wide. Facies articularis cuboidea is round, slightly concave. Facies articularis talaris media is oval, slightly concave. Facies articularis talaris post. is convex, occupies the mediodorsal surface of the node. Both articular surfaces are relatively flat, separated from each other by a relatively shallow sulcus calcanei.

Clethrionomys glareolus (S c hre ber, 1780), (Fig. 26)

The cranial and caudal surfaces of the shaft are obliquely cut. The caudal half of the shaft is bilaterally flattened. Sustantaculum talare is small, flattened, arched in a semicircle. Trochlea peronealis broad and elongated. Sulcus tend. $\mathrm{mm}$. peroneorum is relatively shallow, runs diagonally on the plantar surface of the process. Facies articularis cuboidea is shaped like a bell, is slightly concave. Facies articularis talaris media is oval, slightly concave. Facies articularis talaris post. is situated on the dorsomedial surface of the dorsal tuberal prominence of the bone. It is triangular, narrowing sharply in the caudal direction of the bone. Both articular surfaces are separated from each other by a fairly wide, shallow sulcus. 
(Arvicola terrestris (L in n a e u s, 1758), (Fig. 27)

The bone is sturdy, massive. The cranial and caudal surfaces of the bone are obliquely cut. The bone is widest in the cranial region, the caudal region of the bone is slightly broadened, the centre of the shaft is bilaterally flattened, narrower. Sulcus tend. calcanei is broad, shallow. Sustentaculum talare is very roughly speaking similar to a right-angled triangle. The free margin of the process is convex in the form of an arch, the caudal margin - convex-concave. Sulcus tend. m. flex. dig. fibularis is incised deeply into the shaft of the bone. Trochlea peronealis is right-angled, narrow, the caudal margin is convex-concave. Sulcus tend. mm. peroneorum situated on the plantar surface of the process is relatively shallow and narrow. Facies articularis cuboidea is oval, concave in the form of a basin. The margin of the articular surface is low on the side of the medial surface, the remainder of the articular surface is surrounded by a high and steep margin. Facies articularis talaris media is oval, occupies the dorsal part of sustentaculum talare, is slightly concave. Facies articularis talaris post. is strongly convex, occupies the dorsomedial surface of the node. Both surfaces are separated from each other by a shallow sulcus calcanei.

Ondatra zibethica (L in n a e us, 1766), (Fig. 28)

The bone is flattened dorso-plantarly. The caudal part of the shaft of the bone is bent in the form of a bow in the direction of the axis of the autopodium. Sustentaculum talare is thick, flattened on the dorsal side, slightly convex on the plantar side. Sulcus tend. $m$. flex. dig. fibularis is deeply incised in the shaft of the bone. The free margin of the process is similar to a normal bow in outline, with the apex shifted in the caudal direction. Trochlea peronealis is right-angled, protruding in the cranial direction over facies articularis cuboidea. Sulcus tend. $\mathrm{mm}$. peroneorum on the dorsal surface of the process runs diagonally, on the plantar surface parallel to the long axis of the bone. Both sulci are broad, relatively deep. Facies articularis cuboidea is concave along the dorso-plantar axis, and is situated diagonally in relation to the long axis of the bone. Facies articularis talaris ant. is triangular, occupies the dorsomedial surface of the cranial margin of the bone. Facies articularis talaris media is oval, concave in the form of a basin. Facies articularis talaris post. is relatively short, broad, tongue-shaped in outline. The articular surface is saddle-shaped. Sulcus calcanei is relatively narrow, deep, is similar to the letter $\mathrm{V}$ in outline, 
Pitymys subterraneus (d e S ély s-L ong champs, 1835), (Fig. 29)

The bone is slightly twisted in the long axis, the caudal end of the bone is bent in the direction of the long axis of the autopodium. The cranial and caudal surfaces are cut obliquely. The bone is flattened dorsoplantarly. Sustentaculum talare is arched in the form of a bow, the apical part is inclined in the caudal direction. Sulcus tend. $m$. flex. dig. fibularis is incised deeply in the shaft of the bone. Trochlea peronealis is flat, elongated, protrudes in the cranial direction of the bone. Sulcus tend. $\mathrm{mm}$. peroneorum on the dorsal surface runs parallel, and on the plantar surface - diagonally to the long axis of the bone. Both sulci are shallow gutters. Facies articularis cuboidea is concave in the form of a basin, the marginal edge of the surface is irregular, similar to a circle. Facies articularis talaris media is concave, round. Facies articularis talaris post. occupies the dorsomedial dorsal prominence of the bone. The surface together with the dorsal edge of the bone is similar to a vase in shape with a broad base and elongated slender neck. It reaches almost to the caudal end of the bone. Sulcus calcanei is similar in profile to a letter V.

Microtus Schrank, 1798 (Figs. 30, 31, 32, 33, 34)

The os calcaneum in all the species examined is sturdy, flattened dorsoplantarly, in $M$. arvalis and $M$. agrestis smooth, and in $M$. oecononıus massive and knotty. The cranial and caudal edges are cut obliquely. There is a broad, relatively shallow sulcus tend. calcanei on the caudal edge of the bone. Sustentaculum talare is a flat, relatively small process strongly convex in the form of a bow. In $M$. orcadensis the outline of the free edge is similar to a parrot's beak. Sulcus tend. m. flex. dig. fibularis is incised strongly into the shaft of the bone, with the exception of $M$. nivalis. Trochlea peronealis is relatively high and broad, the craniomedial edge ends on the edge of facies articularis cuboidea in the majority of the species, while in $M$. brandti, $M$. oeconomus, $M$. agrestis it is separated by a shallow sulcus. The lateral edge is undulated. The caudal edge is most highly convex-concave in $M$. nivalis, least so in $M$. oeconomus and $M$. brandti. Sulcus tend. $m$. peronei brevi is distinct, but slightly shallower in $M$. brandti. Sulcus tend. $m$. peronei on the plantar side of the process runs diagonally to the long axis of the process, is deep in $M$. oeconorrus and $M$. pensylvanicus, and has clearly defined limits in the remaining species. A line drawn through the apices of both processes runs diagonaliy to the long axis of the bone. Facies articularis cuboidea is approximately oval in shape, concave, saucer-shaped. Facies articularis talaris media is relatively small, oval, slightly concave, Facies articularis talaris post. is 
situated on the dorsomedial surface of the nodular prominence of the bone, is convex, similar to a triangle.

Lagurus lagurus (P a 11 a s, 1773), (Figs. 35, 36)

The cranial and caudal edges of the bone are parallel, slightly cut diagonally, the lateral edge of the bone extends cranially. The plantar surface is flattened plantolaterally, and there are two nodes on it: the craniomedial and caudal. The first of them passes into the edge of sulcus tend. $m$. flex. dig. fibularis, the second is broad, triangular in outline, situated at the base of the broad and relatively shallow sulcus tend. $m$. calcanei. The cranial end of the bone is broadened, the medial region is slightly flattened on both sides, $2 / 3$ of the caudal part is twisted in in S-shape along the dorsal edge. Sustentaculum talare is flat, long, nose-shaped in outline. Trochlea peronealis is broad, ear-shaped. A line drawn through the apices of both processes transects the long axis of the bone diagonally. Sulcus tend. m. peronei longi is relatively shallow, broad, occupies the plantolateral surface of the process. Facies articularis cuboidea is concave in the form of a basin, occupies the whole cranial surface of the bone with the exception of the craniocaudal node on the plantar surface of the bone. It is slightly inclined in the mediodorsal direction. Facies articularis talaris ant. is very small. Facies articularis talaris media is relatively small, oval, slightly concave. Facies articularis talaris post. is large, tongue-shaped, the cranial region occupies the dorsal surface, and the caudal is directed towards the medial surface of the bone.

\section{Gerbillus gerbillus (O livier, 1801), (Fig. 37)}

The shaft of the bone is elongated. The cranial and caudal surfaces are sharply cut diagonally. Sulcus tend. calcanei is broad, the medial edge of the sulcus forms a high threshold. Sustentaculum talare is set with the long axis of the bone, is relatively small, arched in the form of a bow. Sulcus tend. m. flex. dig. fibularis is relatively shallow. Trochlea peronealis is narrow, elongated. The cranial edge of the bone is separated by a deep sulcus from the margin of facies articularis cuboidea. The free edge of the process is slightly convex, and passes without distinct demarcation on to the lateral surface of the shaft. Sulcus tend. $m$. peronei is relatively shallow, occupies the whole breadth of the plantar surface of the trochlea. Facies articularis cuboidea is similar in outline to a triangle, is concave, has relatively high edges open on the medial side. Facies articularis talaris media is concave, round, relatively small. Facies articularis talaris post. is convex, large, occupies the dorsomedial part of the dorsal convexity. 
Meriones shawi (D u ver noy, 1842), (Fig. 38)

The bone is sturdy, thick. The caudal region of the bone narrows in the dorsal direction, the ends are slightly bent in the direction of the axis of the autopodium. The dorsal edge of the bone rises slightly from the caudal end towards facies articularis post., and falls in a steep arch to fossa calcanea. The caudal surface of the bone is incised in the form of steps in the lateral direction, the cranial surface of the bone is cut in the medial direction. Sustentaculum talare is relatively large, flattened. The outline of the edge is similar to a sharp bow, sulcus tend. m. flex. dig. fibularis is distinct but not deep. Trochlea peronealis is narrow, small, separated from the edge of facies articularis cuboidea by a deep incision. Sulcus tend. $m$. peronei on the dorsal surface of the process is shaped like a gutter, but is broader and shallow on the plantar surface. Facies articularis cuboidea is concave in the form of a basin, slightly oval, indented in a bow-shape on the medial side, slightly more shallowly indented on the lateral side. Facies articularis talaris media is relatively large, oval. Facies articularis talaris distalis is triangular, occupies the dorsomedial surface of the dorsal prominence. The apex of the triangle is situated at the base of sustentaculum talare.

\section{Vandeleuria oleracea (B e n n e t, 1832), (Fig. 39)}

The bone is slender, slightly twisted in the long axis. The terminal surfaces of the bone are lightly cut diagonally, almost parallel. The side edges of the caudal half of the bone are pillar straight. Sulcus tend. calcanei is deep. Sustentaculum talare is flattened, the free edge is similar in outline to half a trapezium. Sulcus tend. $m$. flex . dig. fibularis incises into the shaft of the bone at the base of the process. Trochlea peronealis is similar in shape to an elongated rectangle. Sulcus tend. $\mathrm{mm}$. peroneorum are situated on the free edge of the process and'on its plantar surface. Facies articularis cuboidea is concave, with an irregular marginal line. On the side of the medial surface the articular surface is recessed in the form of a bow. Facies articularis talaris media is oval, slightly concave. Facies articularis talaris post. is tongue-shaped, occupies the dorsomedial surface of the dorsal prominence of the bone. Sulcus calcanei is mediumly deep.

Micromys minutus (P a 11 a s, 1771), (Fig. 40)

The proximal region of the bone is flattened dorsoventrally, frcm sustentaculum talare to the caudal end the bone is bilaterally flattened. The cranial and caudal surfaces of the bone lie parallel to each other, slightly cut. Sustentaculum talare is flattened, similar in shape to a square. 
Sulcus tend. m. flex. dig. fibularis lies on the border of the process and the shaft of the bone. Trochlea peronealis is convexly arched. Sulcus tend. $\mathrm{mm}$. peronearum is shallower on the lateral edge of the process, deeper, sulcate, running diagonally, is situated on its plantar surface. Facies articularis cuboidea atretches in the mediolateral direction, is triangular, with rounded angles, and concave in the form of a basin. Facies articularis talaris media is slightly concave, oval. Facies articularis post. is similar in shape to an elongated isosceles triangle, the apex of which is situated on the dorsal edge of the caudal part of the bone. The articular surface occupies the dorsomedial surface of the dorsal prominence of the bone. Sulcus calcanei is shallow.

\section{Apodemus K a u p, 1829 (Figs. 41, 42)}

The largest and most massive os calcaneum in the genus examined occurs in $A$. flavicollis, the slenderest in $A$. agrarius. In the species examined part of the bone is broadened from the cranial side, and from the caudal side is pillar-shape, flattened bilaterally. The shaft of the bone is slightly twisted. The caudal surface of the bone is obliquely cut. Sulcus tend. calcanei is relatively broad, deepest in $A$. flavicollis, shallowest in A. sylvaticus. Sustentaculum talare is flattened. In A. flavicollis and $A$. sylvaticus the free edge of the process is similar to a sharp bow in outline, in $A$. agrarius - the apex of the bow is shifted in the caudal direction. Sulcus tend. $m$. flex. dig. fibularis is relatively deep, is situated on the border of the shaft and process. Trochlea peronealis in A. sylvaticus and A. flavicollis is long, similar in shape to a rectangle. In the first of these species the caudal edge of the process is distinctly separated from the lateral surface of the shaft, in the second species the free edge of the process passes without a distinct border on to the surface of the shaft. In A. agrarius the process examined is short, the caudal edge is always clearly marked. Sulcus tend. $\mathrm{mm}$. peroneorum is situated on the lateral and plantar surfaces of the process. Facies articularis cuboidea has an open edge on the medial side, in A. flavicollis and A. sylvaticus is irregular in shape, is concave along the mediolateral axis. Facies articularis media is oval, slightly concave along the craniocaudal axis, set at an acute angle to the long axis of the bone. Facies articularis talaris post. is situated on the dorsomedial surface of the dorsal prominence of os calcaneum. The caudal end of the articular surface is triangular, rounded. In $A$. sylvaticus the sides of the triangle are elongated and form an acute angle, in $A$. flavicollis and $A$. agrarius they are similar in shape to a right angle - the sides are short, the articular surface in the first species being considerably broader 
and elongated. Both articular surfaces are separated from each other by a deep, long and broad sulcus calcanei.

\section{Rattus F is che r, 1803 (Fig. 43)}

The os calcaneum in $R$. rattus is slightly smaller and slenderer. In both the species examined the cranial and caudal surfaces of the bone are obliquely cut. The medial and caudal regions of the shaft are cut in the shape of a roof on the dorsal side. Sulcus tendinis calcanei is broad - deeper in $R$. rattus, shallower in $R$. norvegicus. Sustentaculum talare is relatively large, flattened on the dorsal side, convex from the plantar side. The outline of the free edge of the bone is similar to a semicircular bow. In $R$. rattus this process is slenderer. Sulcus tend. m. flex. dig. fibularis is relatively deep, situated on the border of shaft and process. Trochlea peronealis is similar in shape to an elongated right angle, slightly broader and shorter in $R$. rattus, narrower and more elongated in $R$. norvegicus. Sulcus tend. $\mathrm{mm}$. peroneorum is relatively shallow with thickened, rounded edges, runs diagonally on the plantar surface of the process. Facies articularis cuboiciea is concave in the form of a basin, the marginal edge of the articular surface is open on the medial side - the articular surface is convex in this place. Facies articularis talaris media is rounded, slightly concave, in $R$. rattus occupies almost the whole dorsal surface of sustentaculum, in $R$. norvegicus is shifted more in the direction of the centre of the bone. Facies articularis taiaris post. occupies the dorsomedial dorsal prominence of bone. The caudal and of the articular surface is rounded, raised above the caudal part of the dorsal edge of the bone. This surface is slenderer in $R$. rattus. Sulcus tendinis musculi calcanei is relatively deep, broad and long.

\section{Mus musculus L in a e s, 1758 (Fig. 44)}

The cranial and caudal surfaces of the bone are parallel, cut diagonally. The cranial surface of the bone is irregular in shape, the edge running round this surface is open on the medial side. The caudal hali of the shaft is pillar-shape the cranial flattened dorsoplantarly. Sustentaculum talare is flattened, the outline of the free edge is somewhat similar to a hooked nose. Sulcus tend. $m$. flex dig. fibularis incises between the shaft of the bone and prominence. Trochlea peronealis is relatively large, and to a certain extent is similar in outline to a sectional bow. In the cranial part it is slightly broader than in the caudal. Sulcus tend. mm. peroneorum runs on the lateral and plantar surface of the process. The sulcus on the plantar surface of the process is broad, guttershaped, takes a diagonal course. Facies articularis cuboidea roughly speaking is similar in shape to a heart, is concave. Facies articularis talaris media is relatively small, 
oval, situated in the terminal part of the dorsal surface of sustentaculuri: talare. Facies articularis talaris posterior stretches from the dorsal edge of the prominence of the bone, occupying its medial half. The surface is saddleshaped, oval. Sulcus tend. calcanei is relatively shallow, both articular surfaces are similar to each other.

\section{Glis glis (L i n n a e us, 1766), (Fig. 45)}

The cranial surface of the shaft of the bone is cut diagonally slightly more weakly than the caudal surface on which there is a broad, relatively shallow sulcus tend. calcanei. The shaft of the bone is twisted, flattened bilaterally in the perimedial region. Sustentaculum talare is similar to a sectional bow in outline. It is convex on the side of the plantar surface, slightly concave on the side of the dorsal surface. Trochlea peronealis is situated mediocranially on the lateral surface of the shaft. On the lateral and also on the plantar surface of the process there are sulcus tend. mm. peroneorum. The sulcus on the plantar surface is slightly broader, relatively shallow, runs parallel to the long axis of the bone. Facies articularis cuboidea is concave along the latermedial axis of the articular surface. The outline of the marginal line is irregular. On the side of the medial surface the articular is recessed in bow form. The edge surrounding the articular surface is open. Facies articularis talaris ant. is small, triangular, situated on the mediodorsal surface of the cranial edge of the shaft of the bone. Facies articularis talaris media is narrow, elongated, with rounded ends, slightly concave. Facies articularis talaris post. is convex, tongue-shaped, occupies the dorsomedial surface of the dorsal prominence of the bone. Sulcus calcanei is relatively short, deep.

Muscardinus avellanarius (L in n a u s, 1758), (Fig. 46)

The cranial end of the bone is cut vertically, the caudal end diagonally to the long axis of the bone. The shaft of the bone is slightly twisted, the plantar half of the shaft is bilaterally flattened. The caudal end of the bone is slightly broadened, the cranial end flattened on the dorsal side and also broadened. Sulcus tend. calcanei is shallow, depressed in a hollow. Sustentaculum talare is small, thick, slightly convex on the plantar side, the free edge of the process is similar in outline to a semi-circular bow. Sulcus tend. $m$. flex. dig. fibularis is distinct, runs along the boundary between process and shaft. Trochlea peronealis is relatively large, flat, situated on a common axis with sustentaculum talare, set vertically to the Iong axis of the bone. In general outline the shape of the process is simiiar to a low trapezium. Sulcus tend. $\mathrm{mm}$. peroneorum is situated lateroplantarly. It is sulcate, broad, runs transversely to the long axis of the bone. 
Facies articularis cuboidea has a straight edge from the plantomedial side, the remaining part of the edge is arched in the form of a sharp bow. The articular surface is concave in the form of a basin. Facies articularis talaris ant. is small, triangular, situated dorsomedially on the cranial edge of the bone. Facies articularis talaris media is rounded, plano-convex. Facies articularis talaris post. is tongue-shaped, relatively broad, occupies the dorsomedial surface of the dorsal nodal prominence of the bone. Facies articularis talaris ant. et media are separated from each other by a deep sulcus, the long axes of both these surfaces are set in relation to each other at a slightly obtuse angle. Sulcus calcanei is very shallow, facies articularis talaris media et posterior are set in relation to each other at a strongly obtuse angle.

\section{Dryomys nitedula (P a ll a s, 1778), (Fig. 47)}

The cranial surface is slightly, and the caudal surface strongly, cut. Sulcus tend. calcanei is relatively deep. The bone is twisted in the long axis. It is bilaterally flattened in the caudo-medial region, and flatteried dorsoplantarly in the craniomedial region. The outline of the free edge of sustentaculum talare is archshaped. The plantar region of the process is slightly convex, the dorsal region slightly concave. Trochlea peronealis is very elongated, low, with an arched outline. The chief prominence of the arch is shifted in the cranio-medial direction. Sulcus tend. mm. percneorum run on the lateral and plantar surfaces of the process, the second of these two sulci is relatively shallow and wide. Facies articularis cuboidea is concave throughout the length of the mediolateral axis. heartshaped, the concavity of the marginal line is situated on the plantomedial side. Facies articularis talaris ant. occupies a triangular field on the medio-cranial surface of the shaft. Facies articularis talaris media is plaro-convex, relatively small, rounded. Facies articularis talaris post. is elongated situated on the dorsomedial surface of the dorsal convexity of the bone. The caudal region of the articular surface is triangular. Sulcus culcanei is wide and relatively shallow.

Sicista betulina (P a 11 as, 1779), (Fig. 48)

The shaft of the bone is slightly twisted, is slightly wider at the cranial end, and clavate at the caudal end. Facies articularis talaris post. is strongly compressed at the base. The cranial surface of the bone is cut obliquely, the caudal surface vertically. Sulcus tend. calcanei is wide. Sustentaculum talare has an aquiline profile, is flattened. Sulcus tend. $m$. flex. dig. fibularis runs along the border of the shaft of the bone and the process. Trochlea peronealis is flattened. The free edge of the process is 
similar to a halfleaf in outline. Sulcus tend. $\mathrm{mm}$. peroneorum are situated on the lateral and plantar surfaces of the bone. Facies articularis cuboidea is shaped like an isosceles triangle with rounded angles, and is concave in the shape of a basin. Facies articularis talaris media is slightly concave, oval. Facies articularis talaris posterior occupies the dorsomedial surface of the dorsal prominence. The edge dividing the articular surface runs through the middle of the articular surface from the base of sustentaculum talare in a laterocaudal direction. The caudal end of the surface is acute-angled. Both articular surfaces are separated from each other by the deep V-shaped sulcus calcanei.

Cavia porcellus L i n a e us, 1758 (Fig. 49)

The shaft of the bone is sturdy, twisted in the long axis. The terminal ends are bent in the direction of the axis of the autopodium. The cranial and caudal surfaces of the bone are strongly cut. The edge surrounding facies articularis cuboidea runs in a bow-shape, is open from the medial surface side. Sulcus tendinis calcanei occupies the caudolateral surface of tuber calcanei, is concave in a bow-shape. Sustentaculum talare is thick, slightly concave on the dorsal surface side, slightly convex on the plantar surface side. The free edge of the process is similar to a normal bow in outline. Sulcus tend. m. flex. dig. fibularis incises between the process and shaft. Trochlea peronealis is situated on the cranial end of the lateral surface of the bone, is similar to a sectional bow in outline. Sulcus tend. $\mathrm{mm}$. peroneorum run parallel on the dorsal surface of the process, and diagonally on the plantar surface to the long axis of the bone. Facies articularis cuboidea is situated on the mediocranial surface of the shaft. The articular surface is concave-convex along the long axis of the bone. Facies articuiaris talaris ant. is relatively small, has an irregular marginal line, is situated on the medial surface of the craniodorsal edge. Facies articularis talaris media is oval, slightly concave. Facies articularis talaris post. is relativcly short and wide, oval in general outline. It occupies the dorsomedial surface of the dorsal prominence of the os calcaneum. The articular surfact: is convex, divided by a steep edge lying in the extension of the caudal eitge of facies articularis talaris media. Sulcus calcanei is faintly marked, shallow, wide, since both articular surfaces are situated at an obtuse angle.

\section{Chinchilla laniger M o I in a, 1782 (Fig. 50)}

The bone is sturdy, elongated. The cranial surface of the bone is strongly cut obliquely, the caudal surface at a right angle in relation to the long axis of the bone. The caudal half of the bone is right-angled. Sulcus tend, calcanei is wide, faintly concave. Sustentaculum talare is 
relatively small, thick, similar in shape to a trapezium. Sulcus tend. $m$. flex. dig. fibularis incises into the border between shaft and process. Trochlea peronealis is similar to a shallow sectional bow, sulcus tend. $\mathrm{mm}$. peroneorum occupies the whole width of the plantar surface of the process. Facies articularis cuboidea is concave-convex, with an irregular outline of the marginal line. Facies articularis talaris ant. is shaped like an elongated triangle, and occupies the surface lying between facies articularis cuboidea and sustentaculum talare. Facies articularis talaris media is oval, slightly concave, separated from the next surface by a relatively long sulcus calcanei. Facies articularis talaris post. is wide, is situated on the dorsal prominence of the bone. An elongated, S-shaped edge runs along the summit of the bone. The caudal part of the articular surface is rounded.

\section{COMPARATIVE REVIEW OF THE STRUCTURE OF OS CALCANEUM}

\section{IN THE INSECTIVORA AND RODENTTIA EXAMINED}

The os calcaneum is small and delicate in Soricinae, Crocidurinae (with the exception of Suncus murinus), Clethrionomys, Pitymys, Micromys, Mus, Muscardinus, Sicista. In the remaining species the bone is of more massive structure, and in general sturdy.

Twisting of the bone in the long axis occurs in Amblysomus, Erinaceus, Crocidura, Talpa, Sciurinae, Phodopus, Pitymys, Vandeleuria, Apodemus, Glirinae, Sicista.

The dorsoplantar flattening of the shaft occurs in Microtinae, with the exception of Clethrionomys and $M$. brandti.

The shaft of the bone is bilaterally flattened in all the sub-families examined, with the exception of part of Microtinae, Gerbillinae ard Chinchilla, in which roof-shaped flattening of the dorsal region of the shaft occurs.

The cranial region of the bone is broadened in Sciurinae, Cricetinae, Microtinae, Murinxe, Glirinae, Sicista, Talpa. The medial region of the shaft is bilaterally narrowed in Sciurinae, Cricetinae, Ondatra, Arvicola, Clethrionomys, Lagurus, Microtus brandti, Gerbillus, Glirinae, Sicista, Murinae, Cavia.

The caudal and medial regions of equal breadth, bilaterally flattencd, occur in Insectivora, with the exception of Amblysomus and Erinaceus. In the remaining species the cranial region is more broadened.

Both terminal ends of the bone are bent in the direction of the axis of the autopodium in Amblysomus, Neomys, only the bent caudal end of the bone occurs in Erinaceus, Sciurinae, Cricetinae, Ondatra, Pitymys, Mer:ones and certain Murinae. 
Four combinations may be distinguished in the positioning of the cranial and caudal surface in relation to the long axis of the bone:

1) the combination most numerously represented, with both surfaces situated obliquely in one spatial plane, occurs in Insectivora (with the exception of Amblysomus), Gerbillinae, Microtinae (with the exception of Lemmus and Lagurus), Murinae, and situated obliquely in the opposite planes in Chinchilla.

2) vertical cranial surface, caudal surface situated obliquely in relation to the long axis of the bone, occurs in Cynomys, Glirinae, Lemmus, Lagurus, Cricetinae.

3) cranial surface obliquely, and caudal surface vertically, situated in relation to the long axis of the bone, occurs in Sicista, Cavia.

4) both surfaces vertical to the long axis of the bone occurs in Amblysomus and Sciurinae (with the exception of Cynomys).

Sulcus tendinis calcanei is wide in Sciurus, Arvicola, Microtus, Apodemus, Rattus, Sicista, wide and shallow in Erinaceus, Tamias, Cricetus, Lagurus, Glis and Chinchilla, wide and very shallow in Cricetinae, Lemmus, shallow in Sorex, Cynomys, Muscardinus, Cavia, deep in Neomys, Blarina, Ratufa, Citellus, Vandeleuria, Dryomys.

Sustentaculum talare is relatively large in Talpa, Citellus, Sciurus, Cricetinae, Lemmus, Meriones, Rattus, thick in Ondatra, Muscardinus, Chinchilla, prominent in Erinaceus, Blarina, very broad in Amblysomus, relatively small in Microtus, Chinchilla, slight in Lagurus, Clethrionomys, Gerbillus, Sicista, Muscardinus, slender in Crocidura. The process is flattened in Erinaceus, Blarina, Suncus, Talpa, Cricetinae, Lemmus, Lagurus, Clethrionomys, Microtus, Meriones, Murinae, with the exception of Rattus, flattened on the dorsal side in Amblyosomus, Sciurinae, Ondatra, Rattus and Muscardinus, slightly concave on the dorsal side in Glis, Dryomys, Cavia, concave-convex on the dorsal side in Amblysomus, convex on the plantar side in Sciurinae, Ondatra, Rattus, Glirinae, Cavia.

Sustentaculum is situated with the long axis at an angle of $45^{\circ}$ in Talpa, Cricetinae, M. brandti, Clethrionomys, Pitymys, Vandeleuria, Sicista, Cavia.

The long axis of the process is directed caudally in Sciurus, Citellus, $T a-$ mias, Insectivora (with the exception of Talpa), Microtinae (with the exception of Clethrionomys, M. brandti, Pitymys), Gerbillinae, Murinae (with the exception of Vandeleuria). The long axis of the process is directed cranially in Ratufa, Cynomys, Glirinae.

The outline of the free edge of the process is similar to a semicircular bow in Amblysomus, Soricinae, with the exception of Sorex, in Suncus, Sciurinae with the exception of Sciurus, in Cricetus, Phodopus, Microtinae, Gerbillus, Mus, Muscardinus, Cavia, Dryomys similar to the outline 
of a sectional bow in Glis, archshaped bow in Dryomys, sharp bow in Sciurus, Mesocricetus, Apodemus, Ondatra, Pitymys. In Crocidura, Neomys, Arvicola, the caudal edge is concave-convex, in Erinaceus straight, the remaining part of the edge in these species is convex. In Talpa the process is similar in shape to a rectangle, to a triangle in Sorex and Arvicola, to a trapezium in Sorex, Vandeleuria and Chinchilla.

Sulcus tendinis $m$. flexoris digitorum fibularis is wide in Amblysomus, Erinaceus, Sciurinae, Cricetinae, Microtinae, incises into the shaft of os calcaneum in Amblysomus, Sciurinae, Cricetinae, Murinae, Microtinae, Cavia, Chinchilla, runs diagonally to the long axis of the process in Blarina, Crocidura, Suncus, is separated from the shaft by a broad and high crest in Cynomys, by a low, flattened crest in Cricetus, Citellus.

Trochlea peronealis is nodulate in Erinaceus, Amblysomus, Gerbillince, Cavia, Chinchilla, arched in Sciurinae, Cricetinae and Glirinae, in the remaining species this process is in general large, with greatly differentiated structure. The process extends to the cranial edge of os caicaneum in the majority of the species examined, protruding like a step from the cranial edge in Cricetinae, Lemmus, Lagurus, certain Microtı's, Clethrionomys, Vandeleuria, Micromys, Sicista. In Ratufa it is situated halfway along the lateral surface of the bone.

The line connecting sustentaculum talare with trochlea peronealis is directed diagonally in the greater part of the species examined, sustentaculum being situated in the majority of the species more caudally than trochlea. In Sciurinae (with the exception of Citellus, Cynomys) and Gli.rinae the apex of trochlea peronealis is situated more caudally - sustentaculum cranially. In the specimens examined of Cricetinae, Micromus, Vandeleuria, Citellus and Cynomys the line connecting the apices of both processes runs vertically to the long axis of the bone, this line in Sciurinae and Cricetinae being situated more caudally than in the other species.

Facies articularis cuboidea differs greatly in structure in the different species. In the majority of the species it is concave, in Cavia and Chinchilla - concave-convex.

Facies articularis talaris anterior is elongated, ellipsoidal, with crushed ends in Amblysomus, oval, strongly convex in Cynomys, rectangular, vertical to the long axis of the bone in Ratufa, similar in shape to a triangle in Citellus, Cricetinae, Ondatra, Glirinae, Lagurus, Cavia and Chinchilla. Facies articularis talaris media is relatively narrow in Soricinae, Crocidurinae, Glis, broad and very large in Amblysomus. Talpa, Sciurinae, relatively wide and large in Cricetinae, Lemmus, Arvicola, Ondatra, Meriones, Apodemus, Rattus, Cavia, Chinchilla. It is rounded in Pitymys, Gerbillus, Rattus, Dryomys, oval in the remaining species.

The articular surface is convex in Glis, planoconvex in the remaining 
Glirinae, concave-convex in Ratufa, and concave in the remaining species examined.

Facies articularis talaris posterior occupies a dorsal position in Ambiysomus, and a dorsomedial position on the dorsal prominence in the remaining species. In Soricinae and Crosidurinae the articular surface consists of the cranially situated node, the caudal part depressed on the medial surface of the shaft and concave-convex on the lateral surface, at the place of contact with the fibula. An S-shaped dorsal edge runs through the articular surface in Soricinae. In Talpa the place of contact with the fibula is the lateral region of the dorsal surface. In the remaining species there is no connection with the fibula, the articular surface is relatively short in Erinaceus; Microtinae, Mesocricetus, Cavia, elongated in the re. mainder of the species.

\section{DISCUSSION}

The study by Stains (1959) on the mammals of North America formed a wide framework for research on this problem. The authcr, taking into consideration 10 orders of mammals, endeavoured to give very general characters of the structure of os calcaneum in these groups of animals, based often on one species, or a representative of one family. He analysed Rodentia in greater detail, and among them Cricetinae. In relation to the species which I examined, they exhibited considerable agreement with the American species in the corresponding systematic units.

The comprehensive study by Grom ov a (1960) draws attention to the practical use of variations in the structure of os calcaneum and astragalus in identifying bone fragments. The authoress took into consideration only the large mammals of the following orders: Primates, Rodentia, Carnivora, Pinnipedia, Proboscidea, Perissodactyla, Artiodactyla.

Forster (1928) stated that if the shaft of the bone is elongated, sustentaculum becomes shorter. The investigations made confirmed this observation, trochlea peronealis also becoming shorter in the material examined.

The investigations I made revealed the great differences in the structure of os calcaneum in the species examined.

It is a known fact that the os calcaneum in the limb carries out the important function of a lever raising the astragalus and transmitting forward impetus raising the body on to the toes. It would seem that present shape and structure of the bone depend in the first place on the genetic factor, then on weight, size and general shape of the body, age, way in which the limbs are set, lenght of each section of the limbs, 
the way in which they are used (type of walk, digging, swimming, climbing etc.). Among habitat factors the kind of food and character of the substratum must be mentioned, and in the case of digging animals the type of soil and depth of the galleries excavated.

A very legible picture is formed by Insectivora against the background of these factors. Among the representatives of this order of mammals examined in my material, three basic types of structure became evident, represented by Amblysomus, Soricoidea and Erinaceus. The animais mentioned originate from different philogenetic stems (Piveteau, 1958). Species belonging to these types of structure are characterised by differences in the shape of the body, the way in which they move about and use their limbs. The simplest structure of the os calcaneum, in my opinion, is that of Erinaceus, representing the initial form of movement for mammals ( $\mathrm{G} \mathrm{r}$ e g o r y, 1957) - running. The remaining insectivores represent the digging forms, Soricinae and Talpa differ, however, from each other as to size and shape of the body, way in which they move and type of digging - despite considerable differences the ossa calcanei bear a certain stamp of similarity, philogenetically conditioned. They are connected by similar slenderness of bone structure, formation of an additional articular connection with the fibula, certain similarity in the structure and situation of trochlea peronealis. Talpa differs from Soricidae by the marked twisting of the shaft in the long axis, development of the processes in breadth, shift of the articular surface of the hind astragalus in the cranial direction (interval between the articular surface and the end of the bone is about $1 / 3$ of the length of the bone). In Soricidoe, in which the limbs are set with the toes turned distinctly outwards, and the zeugopodium has a large angle of inclination in the dorsal and plantar direction, the articular surface of the hind astragalus is very elongated, the distance between the articular surface and the caudal end of the bone is about $1 / 5-1 / 6$ of the length of the shaft. Amblysomus, a digging animal, similar in the shape of its body to the mole, has a differently constructed os calcaneum which differs from that in the other insectivores examined.

The most interesting group of rodents is formed by Sciuridae - represented in my material by the forms living in trees and on the ground. The general shape of the bone, basin-shaped formation of facies articularis cuboidea, shape of sulcus tend. $m$. peronei longi is common to all the forms examined and is evidence of the great ease of eversion of the foot. In Cynomys and Citellus, which excavate deep galleries in the soil, sulcus tend. m. flex. dig. fibularis of the muscle pressing the sole of the foot to the ground, has a formed steep periaxial edge.

The relations in representatives of Myomorpha are not less interesting. Myomorpha have a large number of features in common with the whole 
group, but the representatives of each subfamily differ, against the background of these features, by their own proper features, connected with the habitat and the way in which they use their limbs.

Cricetinae are represented in my material by Cricetus, Mesocricetus and Phodopus. All these genera have similarly bilaterally flattened shafts, a line connecting the apices of trochlea peronealis and sustentaculum talare is set at a right angle to the long axis of the bone, the processes do not reach the cranial edge. In Cricetus, which digs deep into the soil, tendo $m$. flex. digitorum fibularis runs in a deep sulcus bounded on the periaxial side by a flattened crest, the shaft of the bone is straight. The bone examined in Mesocricetus is similar in some respects to Cricetus, in others to Phodopus. In Phodopus, similar as regards its biology and shape of the body to Microtinae, this bone is markedly twisted in the long axis. Sulcus tend. m. flex. dig. fibularis (also in Mesocricetus) runs in a deep sulcus, but without formation of 'the periaxial crest. Sulcus tend. m. peronei longi, on the other hand, is deep, forms a crest on the periaxial side, being similar in this respect to certain of Microtinae, and differing from the other Cricetinae examined.

Among the Microtinae examined, in the digging forms the shaft of the bone is flattened on the plantar side, adapted to living in underground galleries. These are Lemmus, Microtus (agrestis, arvalis, brandti, oeconomus), Pitymys, and Lagurus, which lives on steppes and digs extensive tunnels and galleries in the ground to a depth of $30 \mathrm{~cm}$., has an os calcaneum flattened on the side of the plantar surface in the cranial region, the caudal end of the bone is slightly laterally twisted, sulcus tend. $m$. flex. dig. fibularis incises deeper into the shaft than in the other Microtinae. In Arvicola and Ondatra - swimming forms - there is a prominent craniomedial tuber on the lateral side of the bone, causing different distri-bution of planes in this region of the bone. The plantar surface of the shaft in Microtus nivalis and Clethrionomys is of an intermediate shape between the first of the groups discussed and the swimming forms. Microtus nivalis is an animal which does not exhibit any special need of digging into the earth, while Clethrionomys, which digs into the earth to a depth of $50 \mathrm{~cm}$., is more similar in structure of the bone to Murinae than to Microtinae.

. The convexity of the plantar surface of the bone and the bilateral flattening is characteristic of representatives of Murinae. The latter character is most distinct in the climbing Vandeleuria, Micromys ard Apodemus.

In the tree-living Glirinae the bone is strongly bilaterally flattened. A representative of Sicistinae - Sicista - which is characterised by the great rapidity of its movements, climbing and running, has this bone 
Table 1.

List of species examined (acc. to S i m ps o n's classification, 1945) and of the length and breadth-length indices of os calcaneum.

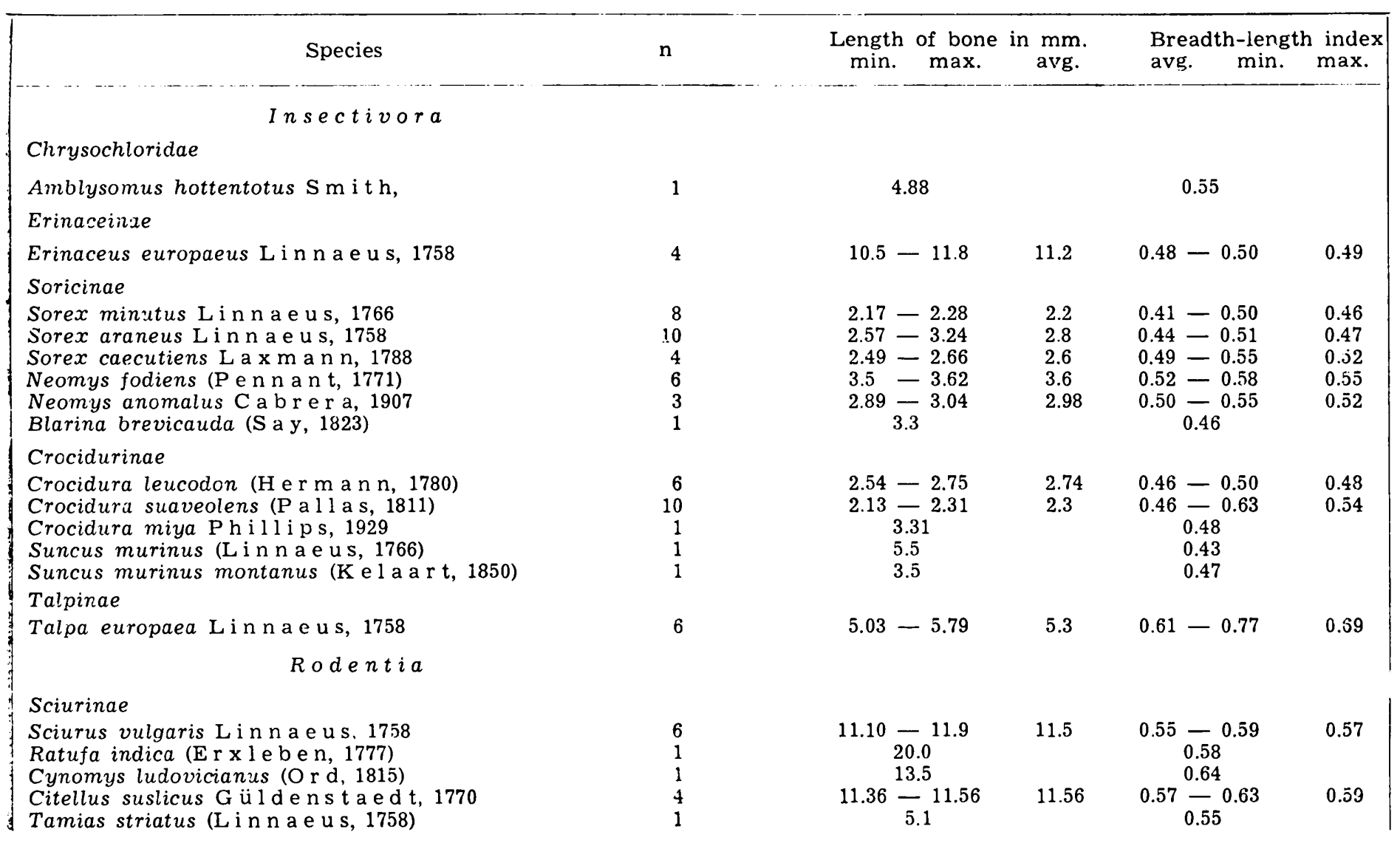




\section{Cricetinae}

Cricetus cricetus ( $\mathrm{L}$ i $\mathrm{n} \mathrm{n}$ a e u s, 1758)

Mesocricetus auratus (W a t e r h o u s e, 1839)

Phodopus sungorus (P a 11 a s, 1773)

Microtinae

Lemmus lemmus ( $\mathrm{Li} \mathrm{n} \mathrm{n}$ a e u s, 1758)

Clethrionomys glareolus (S c h r e b e r, 1780)

Arvicola terrestris ( $\mathrm{L}$ i $\mathrm{n} \mathrm{n}$ a e $\mathrm{u} \mathrm{s}, 1758$ )

Ondatra zibethica ( $\mathrm{L}$ i $\mathrm{n} \mathrm{n}$ a e $\mathrm{u} \mathrm{s}, 1766$ )

Pitymys subterraneus (de S ély $\mathrm{s}-\mathrm{L}$ on $\mathrm{g}$ c h a m p s, 1835) 10

Microtus arvalis ( $\mathrm{P}$ a $1 \mathrm{l}$ a s, 1779)

Microtus pennsylvanicus (O $\mathrm{rd}, 1815)$

Microtus agrestis ( $\mathrm{L}$ i n n a e u s, 1761)

Microtus oeconomus ( $\mathrm{P}$ a $11 \mathrm{a} \mathrm{s}, 1776$ )

Microtus brandti $\mathrm{R}$ a d d e, 1861

Microtus nivalis ( $M$ a $\mathrm{r}$ t i n s, 1842)

Lagurus lagurus (P a 11 a s, 1773)

Gerbillinae

Gerbillus gerbillus (O livi e r, 1801)

Meriones shawi (D u vernoy, 1842)

Murinae

Vandeleuria oleracea (B e n n e t. 1832)

Micromys minutus (P a 11 a s, 1771)

Apodemus flavicollis (M e l c h i o r, 1834)

Apodemus sylvaticus ( $\mathrm{L}$ i n $\mathrm{n}$ a e u s, 1758)

Apodemus agrarius ( $\mathrm{P}$ a 11 a s. 1771)

Rattus rattus ( $\mathrm{L}$ i $\mathrm{n} \mathrm{n}$ a e $\mathrm{us}, 1758$ )

Rattus norvegicus (B e r k e $\mathrm{n}$ ho u t, 1769)

Mus musculus L in a eus, 1758

Glirinae

Glis glis (L i n n a e us, 1766)

Muscardinus avellanari $\iota s$ ( $L$ i n n a e us, 1754)

Dryomys nitedula (P a 11 a s, 1778)

Sicistinae

Sicista betulina (P a 11 a s, 1779)

Cavinae

Cavia porcellus L i n n a u s, 1758

Chinchillidae

Chinchilla laniger M o 1 i n a, 1782 


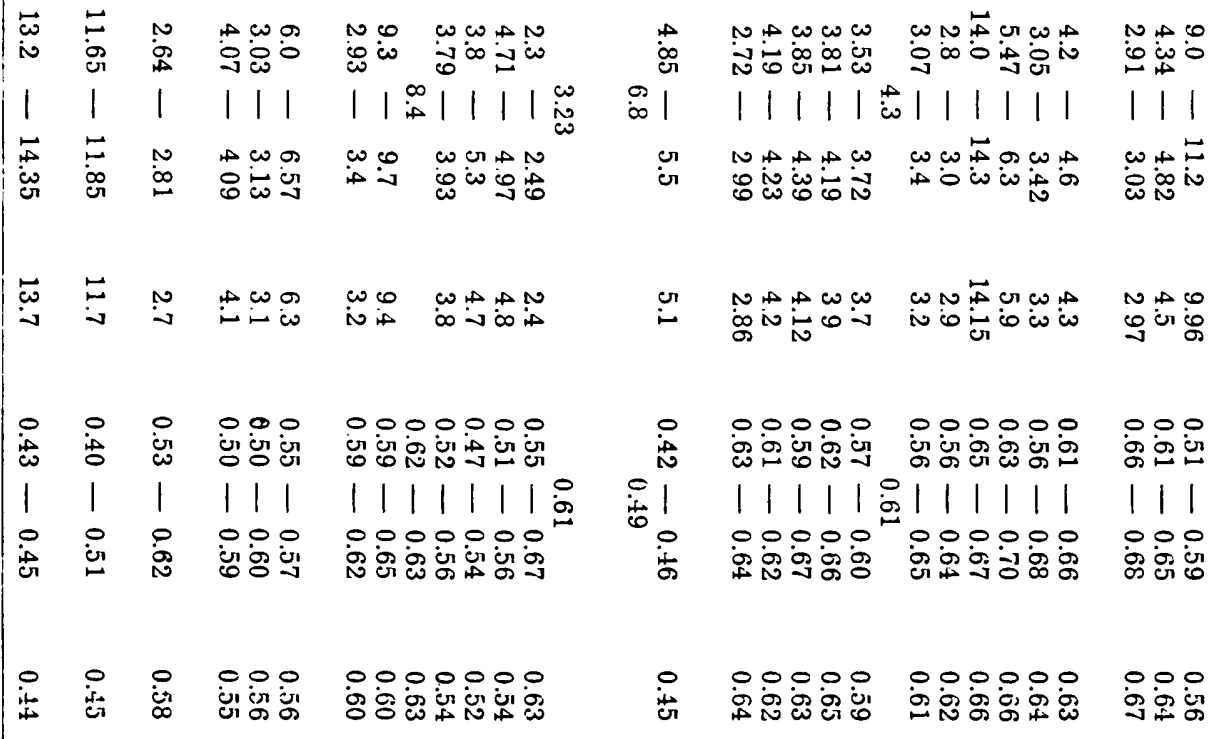


strongly bilaterally flattened in the medial region, widened in shape of a bubble in the caudal region.

The os calcaneum in Gerbillinae differs from the sub-families discussed above by the faint formation of trochlea peronealis.

In all the Myomorpha, trochlea peronealis is situated on the cranial End of the lateral surface of the bone, the terminal end of this process in the majority of Microtinae protrudes in the cranial direction beyond facies articularis cuboidea, in Murinae, Glirinae and Sicista it is slightly withdrawn, reaching at most to the edge of the articular surface.

A separate group is formed by representatives of Hystricomorpha -.Cavia and Chinchilla, which possess a similar structure of the bone and also breadth-length index.

The additional formation of an articular surface with the fibula in Soricidae and Talpa is worthy of notice, and of facies articularis talaris anterior in Sciurinae and Cricetinae, which dig deep below the surface of the ground, of Microtinae, in the steppe Lagurus, the swimming Ondatra, arboreal Glirinae and in Cavia and Chinchilla. The selection of species confirms the observation made by $\mathrm{M} \mathrm{a} \mathrm{n} \mathrm{z} \mathrm{i} \mathrm{j} \mathrm{(1959)} \mathrm{of} \mathrm{the} \mathrm{carpus} \mathrm{of} \mathrm{large}$ mammals. The author states that the number of articular contacts is labile and depends strictly on the functional character of the limb. It increases during the process of evolution with the increase in the violence of the impulses and tensions to which the limbs are subject, moderating their action.

If the material is grouped according to the breadth-length index of the bone (Tab. 1) three classes become apparent: I. $0.40-0.49$, os calcaneum, elongated, narrow, the type represented by Cavia, Chinchilla, Gerbillinice and the majority of Insectivora. II. $0.50-0.59$ Apodemus, Glirinae, the majority of Sciurinae, Cricetus, Sicista, Microtus agrestis, Amblysomus, Neomys, S. caecutiens, C. suaveolens. III. $0.60-0.69$, the class includes Cynomys, Mesocricetus, Phodopus, the remaining species of Murinae, Microtinae, Talpa. The majority of Insectivora belong to the species with processes occupying the minimum breadth in space. The processes most developed in breadth occur in Arvicola, Ondatra, Micromys, Criretinae and Talpa.

The length of os calcaneum in Polish insectivores and rodents in relation to body length is given in table 2. A fairly compact group of Microtinae is distinct - characterised by the lowest figures of $0.029-0.033$. Only Arvicola and Ondatra - swimming forms - differ from the other representatives of the sub-family by their high indices ( 0.037 and 0.04 .5$)$.

The position of Clethrionomys (on the boundary-line between Microtinae and Murinae) deserves emphasis. N a u m ov (1948), in fact on the basis of different characters, defined this species as intermediate between 
Table 2.

Length of os calcaneum of Polish Insectivora and Rodentia in relation to body length.

\begin{tabular}{|c|c|c|c|c|}
\hline S p e c i e $s$ & $\begin{array}{c}\text { Mean } \\
\text { length } \\
\text { of } \\
\text { body }\end{array}: \begin{array}{c}\text { Mean } \\
\text { length } \\
\text { of } \\
\text { bone }\end{array}$ & $S p$ e $c$ i e $s$ & $\begin{array}{c}\text { Mean } \\
\text { length } \\
\text { of } \\
\text { body }\end{array}$ & $\begin{array}{c}\text { Mean } \\
\text { length } \\
\text { of } \\
\text { bone }\end{array}$ \\
\hline \multicolumn{5}{|l|}{ Insectivora } \\
\hline Crocidura suaveolens & $1: 0.034$ & $\begin{array}{l}\text { Clethrionomys } \\
\text { glareolus }\end{array}$ & $1:$ & 0.033 \\
\hline Crocidura leucodon & $1: 0.036$ & Apodemus agrarius & $1: 0$ & 0.035 \\
\hline Neomys anomalus & $1: 0.038$ & Micromys minutus & $1 \cdot$ & 0036 \\
\hline Sorex araneus & $1: 0.039$ & Mus musculus & J & \\
\hline Sorex minutus & & Arvicola terrestris & $1:$ & 0.037 \\
\hline Talpa europaea & $1: 0.040$ & $\begin{array}{l}\text { Rattus norvegicus } \\
\text { Dryomys nitedula }\end{array}$ & 1: & 0.039 \\
\hline Neomys fodiens & $1: 0.042$ & Glis glis & & \\
\hline Erinaceus europaeus ? & $1: 0.046$ & $\begin{array}{l}\text { Muscardinus } \\
\text { avellanarius }\end{array}$ & & \\
\hline Sorex caecutiens & , & Cricetus cricetus & & 0.040 \\
\hline Rodentia & & $\begin{array}{l}\text { Ondatra zibethica } \\
\text { Rattus rattus }\end{array}$ & & \\
\hline Microtus oeconomus & $1: 0.029$ & Apodemus flavicollis & $1:$ & 0.043 \\
\hline Microtus arvalis & $1: 0.030$ & Sicista betulina & & $\cdots$, \\
\hline Microtus agrestis & $1: 0.032$ & Sciurus vulgaris & $1:$ & 0.047 \\
\hline Pitymys subterraneus & $1: 0.032$ & Apodemus sylvaticus & $1:$ & 0.050 \\
\hline Microtus nivalis & $1: 0.033$ & Citellus suslicus & $1:$ & 0.051 \\
\hline
\end{tabular}

both sub-families. The next group is formed by the field and house Murinae $(0.035-0.039)$. An intersting grouping of figures for the relation investigated is formed by representatives of the climbing Glirinae, the forest Murinae, Rattus, Sicista, Sciurus, Cricetus which dig deeply into the soil, and Citellus, the swimming Microtinae, and the mole. The mole, as is known from the data given by $\mathrm{T}$ e odorowa (1927), makes movements with its limbs pushing the earth backwards - similar to the movements made in swimming, Ondatra swims dexterously with the aid of its legs (van den B rink, 1957). M a n z i j (1956) observed cartain similarities in the length relation of different sections of the fore limb in the mole and Pinnipedia.

Of the remaining insectivores, Crocidura is situated on the boundäry line between Murinae and Microtinae, the remaining species are grouped round Glirinae and Sciurus. 
Individual variations in length and shape of the bone examined in eawh th species are shown in table 1.

The figures given should be treated with considerable caution - measurements made of small blocks of irregular shapes like the boniesies examined are never more than approximate. The figures obtaincid, $d$, however, give a certain general picture of the structure, the ratio of length th of os calcaneum to body length supplements an analysis of the materiial al against the background of biological groups.

The investigations made showed that despite the considerable differr-rences in the material, it is possible to distinguish features common to to wider systematic units inherited by all members of a group, irrespectiveve of their present biology and adaptational requirements. In contradistinct-tion to them, features proper to different species or genera connect.edsd with the adaptation of the animals to the requirements of their ow $n^{\prime} n$ habitat are noted. The first of these have been termed by M i 11 e r (1937)7) paleotelic, the second - cenotelic.

Variations occurring in the structure of the shaft in Myomorpinala illustrate how the cenotelic features are outlined against the backgroundid of a paleotelic feature, such as is the bilateral flattening of the shaft. Thuusis in the climbing forms, bilateral tapering of the shaft occurs, in Microtinate which crouches in its underground galleries, there is considerable widen-1ing of the plantar surface of the shaft - bilateral flattening is visible onlyly from the cranial side, in swimming Microtinae there is the formation off the prominent node in the cranial region on the plantar surface of the shaft. A similar analysis can be made for the majority of the featuress examined.

Features which are convergences may be distinguished among cenotelidic features. Among these are, for instance, formation and situation off trochlea peronealis in certain Insectivora (Soricoidea) and Roderitica (Microtinae) connected with eversion of the foot (the trochlea enlarges the angle of friction of $\mathrm{mm}$. peronealis longus et brevis). Also the formatiorn of the $\epsilon$ dge of sulcus tend. $m$. flexoris digitorum fibularis exhibits a certain convergence in Cricetinae and Sciurinae which root deep into the earth. The muscle - by acting on the toes, causes the sole to press firmly to the ground.

It must be added that in animals differing in their way of life and type of habitat from closely related forms, and possessing a definite specialis:ation, particularly strongly accented cenotelic features are observed (e.g. Cynomys as contrasted with the Sciurini examined, Tamias contrasted with Marmotini, Lagurus contrasted with Microtinae).

The results obtained indicate the necessity for continuing research. on the remaining skeletal elements of the limbs of mammals, the articulat- 
ions, and muscles. It will only then be possible, on the basis of an accurate knowledg $\epsilon$ of the biology of different species, to make a functional analysis of the skeleton of these little-known and undoubtedly very intresting animals, and discover the road taken by the evoiution of their limbs.

\section{CONCLUSIONS}

On the kasis of the investigations made by the authoress and from data in literature it was found that:

1. Features common to wider systematic units (paleotelic), and features common to narrower units (cenotelic) occurred in the material investigated. Cenotelic features are adaptational features connected with the way in which the limbs are used and with a defined habitat.

2. The length of os calcaneum depends on the way in which the limbs are used. In climbing animals, animals swimming by means of their hind limbs, and animals digging deep into the ground, os calcaneum is longer in relation to body length. Elongation of os calcaneum in Insectivora, Chinchilla, Cavia, Gerbillinae is accompanied by shortening of sustentaculum talare and trochlea peronealis.

3. Convergent features are found in the structure of os calcaneum. in animals making similar use of their limbs, but belonging to different systematic units.

4. A larger number of articular surfaces in the os calcaneum were found in animals making more violent movements or overcoming with their limbs greater resistance of the habitat.

5. Confirmation of $\mathrm{Hilzh}$ i mer's rule of the progressiveness of steppe animals in comparison with related forest forms is found in the structure of os calcaneum.

6. The structure of os calcaneum in mammals may constitute a taxonomic index in identifying bone fragments, and may also to a certain extent be evidence of the animal's capacity for movement.

\section{REFERENCES}

1. Brink van den, F. H., 1957: Die Säugetiere Europas. P. Parey, Hambur ¿Berlin.

2. Forster, A., 1928: Le calcanéum, dans la série des Mammiféres et chez i'Home. Arch. Anat. Histol. et Embryol., 10: 271-325.

3. Gr e g o r y, W. K., 1957: Evolution emergin. E survey of changing patterns from primeval life to man. Mac Millan Co. 4, New York.

4. [G r om ova, V.] Гром о а, В., 1960: Определитель млекопитающих СССР по костям скелета. Тр. Ком. Изуч. Четверт. Пер. АН СССР, 1-115. Москва. 
5. [M a n zi.j, S. F.] М а н з й, С. Ф., 1956: Особеенности строения млекопитающих в связи с различной функцией грудных конечностей. Сб Пробл. Функц. Морф. Двигатель. Аппарата. Медгиз: 79-82, Ленинград.

6. [M a n z ij, S. F.] M а н и й, С. Ф., 1959: Запястье млекопитающих в свете эволюции и функции их грудных конечностей. АН СССР, :3-32. Киев.

7. Mille r, A. H., 1937: Structural modifications in the Hawaiian Goose (Nesochen sandvichensis). A study in adaptive evolution. Univ. Calif. Publ. Zool., 4?, 1: $1-80$ (acc. to $\mathrm{R}$ in $\mathrm{k} \mathrm{e} \mathrm{r}$ ).

8. [N a u mov, N. P.] Н а у м в, Н. П., 1948: Очерки сравнительной экологии мышевидных грызунов. АН СССР. :1-204 Москва-Ленинград.

9. Pivétea u, J., 1958: Traité de Paleontologie. Masson et Cie, Paris.

10. Rinke r, G. C., 1954: The comparative myology of the mammalian genera Sigmodon, Oryzomys, Neotoma and Peromyscus (Cricetinae) with remarks on their intergeneric relationships. Univ. Mich. Misc. Publ., 83: 1-123.

11. R o m a n k o w o wa, A., 1960: The sesamoid bones of the autopodia of Insectivora and Rodentia. Zool. pol., 10, 3: 225-256. Warszawa.

12. Simps on, G. G., 1945: The principles of classification and classification of mammals. Bul. Amer. Mus. Nat. Hist., 85: 1-350, New York.

13. Stains, H. J., 1959: Use of the calcaneum in studies of taxonomy and food habits. J. Mammal., 40, 3: 392-401.

14. St e l m a si ak, M. et al., 1958: Mianownictwo anatomiczne. Państw. Zakł. Wyd. Lek., 1-430, Warszawa.

15. Todorowa, Z., 1927: Die Entstehung der Grabanpassungen bei 'Talpa eurupaea. Morphol. Jb., 57: 381-409.

Plant Protection Institute,

Poznań, Grunwaldzka 189.

\section{STRESZCZENIE}

Przebadano 251 kończyn osobników należących do 50 gatunków (Tabela 1). Przeanalizowano budowę kości piętowej u poszczególnych gatunków. Wyìoniono cechy wspólne dla szerszych jednostek systematycznych. Stwierdzono wystąpienie cech wspólnych u zwierząt należących do poszczególnych podrodzin, charakiteryzujących się podobnym sposobem poruszania' się i posługíwania kończynami.

U zwierząt wykonujących pođobne czynności kończynami, mimo przynależności do czasem dalekich od siebie jednostek systematycznych stwierdzono wystapienie cech będących konwergencjami. I tak pewne podobieństwa anatomiczne występują u Soricinae i Crocidurinae, - Sciurinae i Glirinae, - Microtinae i Murinae - Cavia, Chinchilla i Gerbillinae.

U zwierząt wykonujących kończynami ruchy gwaltowniejsze, lub pokonywujących większy opór środowiska stwierdzono wyksztalcenie dodatkowych powjerzchni stawowych, oraz wydłużenie kości w odniesieniu do długości ciała (Tabela 2).

Wydłużeniu kości piętowej u niektórych owadożernych, Chinchilla, Cavia, Gerbillinae towarzyszy skrócenie się sustentaculum talare i trochlea peronealis (Tabela $1 \perp$ wskaźnik szerokościowo-długościowy).

W budowie kości piętowej została potwierdzona reguła $\mathrm{Hilzh}$ i me r a o progresywności zwierząt stepowych w porównaniu z formami pokrewnymi leśnymi.

$\mathrm{Na}$ podstawie przeprowadzonej analizy stwierdzono, że budowa kości piętowej może stanowić taksonomiczną wskazówkę przy oznaczaniu szczątków kostnych, może również $w$ pewnym stopniu świadczyć o ruchowych możliwościach kończyny. 